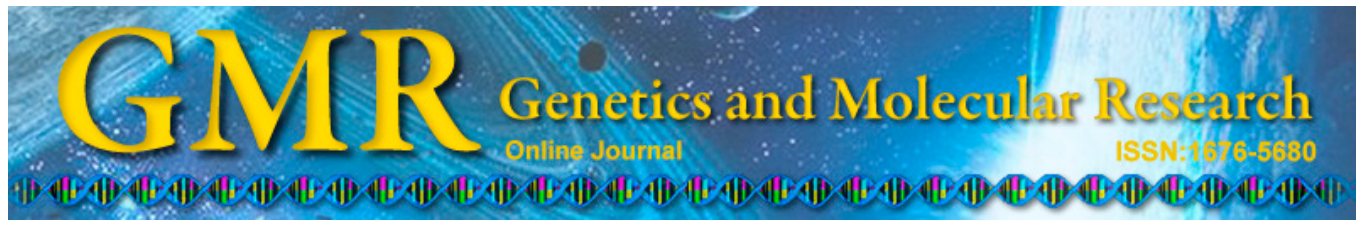

\title{
Changes and clinical significance of serum vaspin levels in patients with type 2 diabetes
}

\author{
L. Yang*, S.J. Chen*, G.Y. Yuan, D. Wang and J.J. Chen \\ Department of Endocrinology, Affiliated Hospital of Jiangsu University, \\ Zhenjiang, Jiangsu Province, China \\ *These authors contributed equally to this study. \\ Corresponding author: G.Y. Yuan \\ E-mail: yuanguo_yue@126.com
}

Genet. Mol. Res. 14 (3): 11356-11361 (2015)

Received December 10, 2014

Accepted May 11, 2015

Published September 25, 2015

DOI http://dx.doi.org/10.4238/2015.September.25.2

ABSTRACT. We investigated serum visceral adipose tissue-derived
serpin (vaspin) levels in patients with normal glucose regulation
and recently diagnosed type 2 diabetes $(\mathrm{T} 2 \mathrm{DM}$ ) and explored the
association between vaspin and body mass index, age, gender, glucose,
lipid metabolism, and insulin sensitivity. Fasting serum vaspin levels
in 66 patients with T2DM and 48 normal subjects were detected using
enzyme-linked immunosorbent assay. We found that serum vaspin
levels in the $\mathrm{DM}$ group were $0.65 \pm 0.13 \mu \mathrm{g} / \mathrm{L}$ in non-obese patients and
$1.13 \pm 0.25 \mu \mathrm{g} / \mathrm{L}$ in obese patients. Serum vaspin levels in the control
group were $0.38 \pm 0.18 \mu \mathrm{g} / \mathrm{L}$ in non-obese patients and $0.95 \pm 0.11 \mu \mathrm{g} / \mathrm{L}$
in obese patients. Average serum vaspin levels were significantly higher
in obese patients than in non-obese patients in both the DM group and
control group. In the DM group, the serum vaspin level was $0.76 \pm 0.22$
$\mu \mathrm{g} / \mathrm{L}$ in males and $0.92 \pm 0.35 \mu \mathrm{g} / \mathrm{L}$ in females. In the control group,
the serum vaspin level was $0.48 \pm 0.14 \mu \mathrm{g} / \mathrm{L}$ in males and $1.05 \pm 0.21$
$\mu \mathrm{g} / \mathrm{L}$ in females. Association analysis showed that serum vaspin levels
were significantly associated with body mass index, waist-to-rip ratio
(WHR), fat percentage, triglyceride, fasting plasma insulin, and insulin
sensitivity index. Stepwise multiple regression analysis showed that 
gender, insulin sensitivity index, and WHR were the most significant independent factors affecting vaspin. Therefore, serum vaspin levels were significantly elevated in obese people and were independently associated with WHR, gender, and index sensitivity index.

Key words: Insulin resistance; Visceral adipose tissue-derived serpin; Diabetes

\section{INTRODUCTION}

Studies have shown that there are more than 100 secreted proteins expressed in adipose tissue, most of which function through the autocrine or paracrine system. The secretory functions in different parts of adipose tissue and their pathogenesis status in obesity and insulin resistance are not completely the same. The association between abdominal visceral fat accumulation, insulin resistance, and type 2 diabetes mellitus (T2DM) has attracted attention. Visceral adipose tissue-derived serpin (vaspin) is an insulin-sensitizing adipokine first identified in the visceral adipose tissues of the Otsuka Long-Evans Tokushima Fatty DM obese rats (Hida et al., 2005) and belongs to the serine protease inhibitor superfamily (Lago et al., 2007). Vaspin is composed of 415, 412, and 414 amino acids in humans, rats, and mice, respectively (Hida et al., 2005). The results of worldwide studies examining the relationship between vaspin and T2DM have been inconsistent, and domestic studies on vaspin in T2DM patients are rare. In this study, we examined changes in serum vaspin level in recently diagnosed T2DM patients to explore the relationship between serum vaspin level and age, gender, body mass index (BMI), glucose metabolism, lipid metabolism, and other hormones.

\section{MATERIAL AND METHODS}

\section{General information}

Sixty-six cases of inpatients and outpatients with DM (DM group) were randomly collected in our hospital from September 2006 to January 2008, including 32 males and 34 females; 36 patients were obese and 30 were non-obese. None had serious complications. DM was diagnosed according to 1997 ADA diagnostic criteria. Obesity diagnosis was based on the Asian adult obesity grading standards of the Asia-Pacific region, and BMI $\geq 25$ was defined as obesity and BMI $<25$ as non-obesity. The normal control group contained 48 patients and included 22 males and 26 females as well as 21 cases of simple obesity and 27 cases of nonobesity. There was no statistically significant difference between the 2 groups in gender $(\mathrm{P}>$ 0. 05). All DM patients were newly diagnosed and had not received any treatment, including diet, exercise, or medication. Type $1 \mathrm{DM}$ patients, female patients at childbearing age (those who take contraceptive drugs), patients with secondary obesity, and patients with DM caused by Cushing psychosis were excluded from the study. All included patients had no history of ketoacidosis, coronary heart disease, kidney disease, and other serious complications of DM. Patients with hypertension controlled their blood pressure below 140/90 $\mathrm{mmHg}(1 \mathrm{mmHg}=$ $0.133 \mathrm{kPa}$ ) with hypertensive medication. All the patients signed informed consent and this study was approved by the Ethics Committee of Affiliated Hospital of Jiangsu University. 


\section{Determination of serum vaspin}

The human vaspin enzyme-linked immunosorbent kit was from Phoenix Pharmaceutical (Burlingame, CA, USA). The lowest measurable concentration was $0.05 \mu \mathrm{g} / \mathrm{L}$ with an inter batch coefficient of variation $<6 \%$ and intra-batch coefficient of variation $<4 \%$.

\section{Determination of various parameters}

When the patients were evaluated only in their underwear and without their shoes or hat, the accuracy of height $(\mathrm{cm})$ and weight $(\mathrm{kg})$ measurements were $0.1 \mathrm{~cm}$ and $0.1 \mathrm{~kg}$, respectively.

BMI was determined using the following equation: BMI $=$ weight $/$ height ${ }^{2}\left(\mathrm{~kg} / \mathrm{m}^{2}\right)$. According to the methods recommended by the World Health Organization in 1995, waist circumference was measured as the horizontal circumference at the midpoint of the lower edge of the ribs and the iliac ridge line, while hip circumference was measured as maximum circumference of the buttocks. The accuracy of circumference measurement was $0.1 \mathrm{~cm}$. Waist-to-hip ratio (WHR) was determined as: WHR = waist / hip. The normal ratios were $<0.90$ in males and $<0.85$ in females. Body fat percentage (\%) was determined as: body fat $=1.2 \times \mathrm{BMI}+0.23 \times$ age -16.2 in males, body fat $=1.2 \times \mathrm{BMI}+0.23 \times$ age -5.4 in females (Deurenberg et al., 1991). Insulin sensitivity index (ISI) $=22.5 /$ [fasting glucose $(\mathrm{mM}) \mathrm{x}$ fasting insulin $(\mathrm{mU} / \mathrm{L})]$. For specimen collection and processing, the venous blood of fasted patients for 12-14 $\mathrm{h}$ were taken the following morning. Blood glucose, plasma total cholesterol (TC), triglyceride (TG), high density lipoprotein-cholesterol (HDL-C), low-density lipoprotein cholesterol (LDL-C), and blood insulin were measured. Some of the serum was separated and stored at $-70^{\circ} \mathrm{C}$.

\section{Statistical analysis}

The SPSS10.0 statistical software was used for analysis (SPSS, Inc., Chicago, IL, USA). The $t$-test, $\chi^{2}$ test, linear correlation analysis, and stepwise multiple regression were used according to the research purposes and data types, respectively, and measured data are reported as means \pm standard deviation.

\section{RESULTS}

\section{General information and laboratory test results}

There was no significant difference in age, gender, BMI, WHR, body fat, blood pressure, TC, HDL-C, LDL-C, and vaspin between the control group and DM group (Tables 1 and 2).

Table 1. General information in type 2 diabetes patients and normal controls (means \pm SD).
\begin{tabular}{lccccccc}
\hline Group & Cases & Age (years) & BMI $\left(\mathrm{kg} / \mathrm{m}^{2}\right)$ & WHR & Body fat $(\%)$ & SBP $(\mathrm{mmHg})$ & DBP $(\mathrm{mmHg})$ \\
\hline Control group & 48 & $53.7 \pm 7.5$ & $23.5 \pm 2.7$ & $0.84 \pm 0.12$ & $30.6 \pm 6.7$ & $120 \pm 12$ & $71 \pm 9$ \\
DM group & 66 & $56.3 \pm 6.4$ & $24.4 \pm 2.2$ & $0.86 \pm 0.04$ & $29.5 \pm 5.2$ & $124 \pm 6$ & $70 \pm 6$ \\
\hline
\end{tabular}


Table 2. Laboratory test results in type 2 diabetes patients and normal controls (means \pm SD).

\begin{tabular}{lccccc}
\hline & FBG $(\mathrm{mM})$ & PG2H $(\mathrm{mM})$ & HBA1C $(\%)$ & TC $(\mathrm{mM})$ & TG $(\mathrm{mM})$ \\
\hline Control group & $5.4 \pm 0.4$ & $5.9 \pm 1.2$ & $4.99 \pm 1.14$ & $4.19 \pm 1.12$ & $1.23 \pm 0.59$ \\
DM group & $10.2 \pm 4.3^{\mathrm{b}}$ & $18.1 \pm 6.6^{\mathrm{b}}$ & $8.59 \pm 1.87^{\mathrm{b}}$ & $5.12 \pm 0.96$ & $2.43 \pm 0.82^{\mathrm{a}}$ \\
& HDL-C $(\mathrm{mM})$ & LDL-C $(\mathrm{mM})$ & FINS $(\mathrm{mU} / \mathrm{L})$ & ISI & Vaspin $(\mu \mathrm{g} / \mathrm{L})$ \\
Control group & $1.33 \pm 0.3$ & $3.27 \pm 1.11$ & $7.7 \pm 4.0$ & $1.87 \pm 0.74$ & $1.15 \pm 0.71$ \\
DM group & $1.3 \pm 0.63$ & $2.95 \pm 0.84$ & $9.3 \pm 4.8^{\mathrm{a}}$ & $3.24 \pm 1.87^{\mathrm{a}}$ & $1.01 \pm 0.52$ \\
\hline
\end{tabular}

Compared with the control group, ${ }^{\mathrm{a}} \mathrm{P}<0.01,{ }^{\mathrm{b}} \mathrm{P}<0.001$.

\section{Obesity impact on serum vaspin levels}

Serum vaspin levels in the DM group were $0.65 \pm 0.13 \mu \mathrm{g} / \mathrm{L}$ in non-obese patients and $1.13 \pm 0.25 \mu \mathrm{g} / \mathrm{L}$ in obese patients. Serum vaspin levels in the control group were $0.38 \pm$ $0.18 \mu \mathrm{g} / \mathrm{L}$ in non-obese patients and $0.95 \pm 0.11 \mu \mathrm{g} / \mathrm{L}$ in obese patients. Average serum vaspin levels were higher in obese patients than in non-obese patients in both the DM and control groups $(\mathrm{P}<0$ 001).

\section{Gender impact of serum vaspin levels}

The gender difference in serum vaspin levels was significant, which were higher in females than in males. In the DM group, the serum vaspin level was $0.76 \pm 0.22 \mu \mathrm{g} / \mathrm{L}$ in males and $0.92 \pm 0.35 \mu \mathrm{g} / \mathrm{L}$ in females, $(\mathrm{P}<0.001)$. In the control group, the serum vaspin level was $0.48 \pm 0.14 \mu \mathrm{g} / \mathrm{L}$ in males and $1.05 \pm 0.21 \mu \mathrm{g} / \mathrm{L}$ in females $(\mathrm{P}<0.001)$, as shown in Table 3.

Table 3. Vaspin levels in different genders.
\begin{tabular}{llcc}
\hline Group & Gender & Cases & Serum vaspin $(\mu \mathrm{g} / \mathrm{L})$ \\
\hline Control group & Male & 22 & $0.48 \pm 0.14$ \\
& Female & 26 & $1.05 \pm 0.21^{\mathrm{b}}$ \\
DM group & Male & 32 & $0.76 \pm 0.22$ \\
& Female & 34 & $0.92 \pm 0.35^{\mathrm{a}}$ \\
\hline
\end{tabular}

Compared with males in the same group, ${ }^{\mathrm{a}} \mathrm{P}<0.01,{ }^{\mathrm{b}} \mathrm{P}<0.001$.

\section{Serum vaspin levels and clinical association analysis}

Association analysis revealed that the serum vaspin levels were significantly associated with BMI, WHR, \% body fat, blood insulin, and ISI in both males and females, but they were not associated with age, TG, TC, HDL-C, LDL-C and blood glucose. We set the vaspin as the dependent variable and gender, age, BMI, WHR, \% body fat, systolic blood pressure, diastolic blood pressure, TC, TG, blood glucose, ISI, blood insulin, and other indicators as independent variables. Stepwise multiple regression analysis showed that gender, ISI, and WHR were the most significant factors affecting vaspin levels (correlation coefficient: $R^{2}=0.161, R^{2}$ $\left.=0.183, R^{2}=0.216, \mathrm{P}<0.01\right)$.

\section{DISCUSSION}

Obese individuals typically exhibit fat cell hypertrophy and an increased number in 
fat cells, which can lead to an increase or decrease in the expression of endogenous hormones in fat cells. This can cause insulin resistance (Trayhurn and Beattie, 2001). Insulin resistance leads to the hypersecretion of insulin to maintain normal blood glucose; when insulin secretion cannot meet the needs of glucose regulation, blood glucose levels increase. Numerous studies have confirmed that insulin resistance not only causes DM, but also is a common risk factor of hypertension, dyslipidemia, and atherosclerosis (Youn et al., 2008). In this study, we found that vaspin is a fat-derived signal that may be involved in the occurrence of insulin resistance and T2DM.

Youn et al. (2008) found that patients with obesity or abnormal insulin sensitivity had elevated serum vaspin levels. Additionally, serum vaspin in obese patients was higher than that in non-obese patients in the same group. Simple correlation analysis suggested that total body fat content was significant related to BMI, WHR, \% body fat, and vaspin. Some prospective studies showed that WHR can reflect abdominal and intra-abdominal fat content, which also show important associations with a range of metabolic syndromes, such as insulin resistance, hyperinsulinemia, and impaired glucose tolerance. In this study, multiple regression analysis confirmed that WHR which, reflecting the abdominal obesity, was independent factor affecting vaspin level. This indicates that vaspin levels are associated with obesity type and that visceral fat is closely related to vaspin. The mechanism of higher serum vaspin in levels in intra-abdominal obesity patients may be that the quality and quantity of vaspin secretion differs between subcutaneous adipose tissue and intra-abdominal adipose tissue.

This study showed that differences in serum vaspin levels between genders were statistically significant; the serum vaspin level in females was significantly higher than that in males. Our results were consistent with the results of Seeger et al. (2008). The reasons for the gender difference remain unclear. Some studies have shown that adiponectin (Nishizawa et al., 2002) and leptin levels (Horn et al., 1996; Ma et al., 1996) are affected by gender, and that androgen may suppress the expression of 2 adipokines. High estrogen levels result in increased leptin level, which may explain the increased vaspin levels as well.

Hida et al. (2005) found that the application of insulin or insulin sensitizer treatment in diabetic rat models could restore rat peritoneal fat-type serine protease inhibitor gene expression and serum vaspin to normal control levels. Feeding obese mice a high-sugar diet while performing vaspin intraperitoneal injection would significantly improve glucose tolerance and insulin sensitivity and restore blood glucose levels. In addition, Gettins (2002) found that vaspin could reverse insulin resistance-related gene expression of proteins such as leptin, resistin, tumor necrosis factor- $\alpha$ and sugar transporters- 4 genes in obese mice. Gene chip detection showed that vaspin treatment in obese mice can reverse $50 \%$ of the gene expression induced by a high-fat or high-sugar diet. The results of this study also confirmed that vaspin was significantly related to ISI, suggesting that vaspin may be involved in the generation of insulin resistance.

Few studies examining vaspin levels have been reported in humans, and thus its pathophysiological significance in humans remains unclear. This study included a limited sample size, and further studies are needed to clarify the relationship between vaspin and sex hormones as well as its participation in intra-abdominal obesity formation.

\section{REFERENCES}

Deurenberg P, Weststrate JA and Seidell JC (1991). Body mass index as a measure of body fatness: age and sex-specific prediction formulas. Br. J. Nutr. 65: 105-114. 
Gettins PG (2002). Serpin structure, mechanism, and function. Chem. Rev. 102: 4751-4804.

Hida K, Wada J, Eguchi J, Zhang H, et al. (2005). Visceral adipose tissue-derived serine protease inhibitor: a unique insulin-sensitizing adipocytokine in obesity. Proc. Natl. Acad. Sci. U. S. A. 102: 10610-10615.

Horn R, Geldszus R, Pötter E, von zur Mühlen A, et al. (1996). Radioimmunoassay for the detection of leptin in human serum. Exp. Clin. Endocrinol. Diabetes 104: 454-458.

Lago F, Dieguez C, Gómez-Reino J and Gualillo O (2007). The emerging role of adipokines as mediators of inflammation and immune responses. Cytokine Growth Factor Rev. 18: 313-325.

Ma Z, Gingerich RL, Santiago JV, Klein S, et al. (1996). Radioimmunoassay of leptin in human plasma. Clin. Chem. 42: 942-946.

Nishizawa H, Shimomura I, Kishida K, Maeda N, et al. (2002). Androgens decrease plasma adiponectin, an insulinsensitizing adipocyte-derived protein. Diabetes 51: 2734-2741.

Seeger J, Ziegelmeier M, Bachmann A, Lössner U, et al. (2008). Serum levels of the adipokine Vaspin in relation to metabolic and renal parameters. J. Clin. Endocrinol. Metab. 93: 247-251.

Trayhurn P and Beattie JH (2001). Physiological role of adipose tissue; white adipose tissue as an endocrine and secretory organ. Proc. Nutr. Soc. 60: 329-339.

Youn BS, Klöting N, Kratzsch J, Lee N, et al. (2008). Serum vaspin concentrations in human obesity and type 2 diabetes. Diabetes 57: 372-377. 